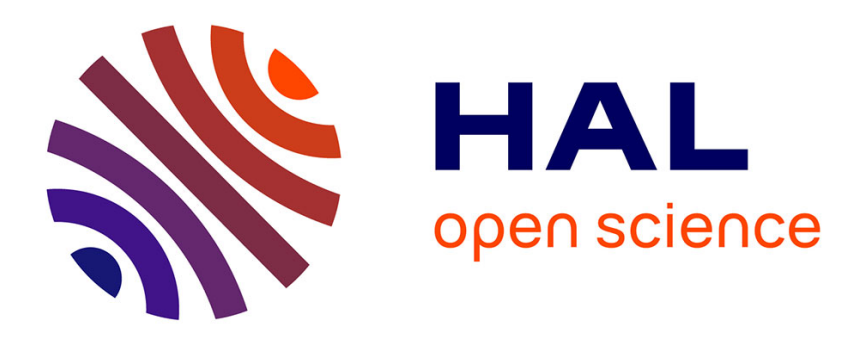

\title{
El tríptico del diablo. En torno al libro de Sendebar
} Federico Bravo

\section{To cite this version:}

Federico Bravo. El tríptico del diablo. En torno al libro de Sendebar. Bulletin Hispanique, 1997, 99 (2), pp.347-371. 10.3406/hispa.1997.4944 . halshs-02062554

\section{HAL Id: halshs-02062554 \\ https://shs.hal.science/halshs-02062554}

Submitted on 9 Mar 2019

HAL is a multi-disciplinary open access archive for the deposit and dissemination of scientific research documents, whether they are published or not. The documents may come from teaching and research institutions in France or abroad, or from public or private research centers.
L'archive ouverte pluridisciplinaire HAL, est destinée au dépôt et à la diffusion de documents scientifiques de niveau recherche, publiés ou non, émanant des établissements d'enseignement et de recherche français ou étrangers, des laboratoires publics ou privés. 


\section{El tríptico del diablo. En torno al libro de Sendebar} Federico Bravo

\section{Citer ce document / Cite this document :}

Bravo Federico. El tríptico del diablo. En torno al libro de Sendebar. In: Bulletin Hispanique, tome 99, n², 1997. pp. 347-371; doi : https://doi.org/10.3406/hispa.1997.4944

https://www.persee.fr/doc/hispa_0007-4640_1997_num_99_2_4944

Fichier pdf généré le 08/05/2018 


\title{
Résumé
}

Partant de l'analyse de l'exemplum de la fontaine magique et à la lumière de l'architecture du livre de Sendebar, dont le présent travail s'efforce de mettre en lumière la cohésion structurale, l'auteur émet I'hypothèse d'un glissement survenu au cours de la transmission du livre ayant déplacé, à l'intérieur du recueil, l'exemplum intitulé Nomina de la huitième à la dix-huitième position : le récit manquant à la collection ne serait plus, dès lors, le deuxième conte du troisième vizir mais le premier conte du septième vizir.

\section{Resumen}

Partiendo del análisis del exemplum de la fuente mágica y atendiendo a la organización general del Sendebar, de cuya coherencia estructural se intenta dar cuenta aquí, el autor emite la hipótesis de un corrimiento interno, producido en algún momento de la transmisión del libro, del exemplum titulado Nomina, desplazado desde la octava hasta la decimoctava posición : el relato que se ha dado por perdido no sería, pues, el segundo cuento del tercer visir sino el primero del séptimo visir.

\begin{abstract}
By analysing the magical fountain's tale and the general structure of the Book of Sindibad, one has tried to account for the structural coherence of the work. The author suggests the hypothesis that the tale entitled Nomina has been moved from the eighth position to the eighteenth position. Therefore the tale which has been considered to be lost would not be the second tale told by the third Vizier but the first tale narrated by the seventh Vizier.
\end{abstract}




\title{
EL TRÍPTICO DEL DIABLO \\ En torno al libro de Sendebar
}

\author{
Federico BRAVO*
}

\begin{abstract}
Partant de l'analyse de l'exemplum de la fontaine magique et à la lumière de l'architecture du livre de Sendebar, dont le présent travail s'efforce de mettre en lumière la cohésion structurale, l'auteur émet l'hypothèse $d$ 'un glissement survenu au cours de la transmission du livre ayant déplacé, à l'intérieur du recueil, l'exemplum intitulé Nomina de la huitième à la dix-huitième position : le récit manquant à la collection ne serait plus, dès lors, le deuxième conte du troisième vizir mais le premier conte du septième vizir.
\end{abstract}

Partiendo del análisis del exemplum de la fuente mágica y atendiendo a la organización general del Sendebar, de cuya coherencia estructural se intenta dar cuenta aquí, el autor emite la hipótesis de un corrimiento interno, producido en algún momento de la transmisión del libro, del exemplum titulado Nomina, desplazado desde la octava hasta la decimoctava posición : el relato que se ha dado por perdido no sería, pues, el segundo cuento del tercer visir sino el primero del séptimo visir.

By analysing the magical fountain's tale and the general structure of the Book of Sindibad, one has tried to account for the structural coherence of the work. The author suggests the hypothesis that the tale entitled Nomina has been moved from the eighth position to the eighteenth position. Therefore the tale which has been considered to be lost would not be the second tale told by the third Vizier but the first tale narrated by the seventh Vizier.

Mots-clés : Sendebar - Exemplum - Conte médiéval.

Perteneciente a la rama oriental de la tradición sendebaresca, la versión hispánica del libro de Sendebar o, como lo bautizó Amador de los Ríos, Libro de los engaños e los asayamientos de las mujeres, incluye en octava posición un breve pero enigmático exemplum cuyo contenido, si bien parcialmente elucidado en lo que a la lógica argumental del texto se refiere, no ha sido objeto

* Université Michel de Montaigne-Bordeaux III, Institut d'Études Ibériques, Domaine Universitaire. 33405 Talence. France.

B. Hi., T. $99,1997, \mathrm{n}^{\circ} 2$, p. 347 à 371. 
todavía de una descripción detallada que dé cuenta de todos los problemáticos pormenores de su desarrollo ni de la posición que ocupa el relato dentro de la estructura general del libro. Se trata del Enxemplo de cómmo vino la muger e dixo que matase el Rey a su fijo, e diole enxemplo de un fijo de un rey, e de su privado cómmo lo engañó, recogido por María Jesús Lacarra en su edición crítica bajo el lemma Fontes, aunque igualmente conocido como el cuento del príncipe y la fuente, e inspirado en motivos bien repertoriados y conocidos de la cuentística tradicional ${ }^{1}$. El elíptico desarrollo de la intriga, que ha valido al relato, entre otros, los calificativos de " extraño ${ }^{2}$ » y de « incongruente $^{3}$ ", ha dejado suponer posibles errores de transmisión imputables ya al copista ya al traductor en algún momento de su compleja historia ${ }^{4}$. El presente trabajo -cuya primera parte no puede ser más modesta en cuanto a sus objetivos, ya que se sitúa en el nivel más elemental de la comprensión literal del textopretende despejar algunas de las incógnitas que han quedado pendientes una vez resuelto el enigma de la intriga, y analizar, en un segundo tiempo, las implicaciones estructurales que revisten las correspondencias existentes entre éste y otros relatos del Sendebar en relación con la arquitectura general del libro 5 .

\section{I. - EL CUENTO “FONTES"}

Et venit ad quendam fontem, de quo quicumque bibebat si masculus erat vertebatur in feminam, et si femina erat vertebatur in masculum.

Historia septem sapientum, I, 6.

El texto relata las desventuras de un príncipe que, prometido a la hija de otro rey, es engañado por el valido de su padre cuando, de camino hacia el palacio de la prometida al que el valido debía conducirlo, éste lo abandona

1. Se trata, esencialmente, de los motivos D 12 «Transformación de un hombre en mujer $;$ y D 925 "Fuente mágica " (Stith Thompson, Motif-Index of Folk-Literature. A classification of narrative elements in folktales, ballads, myths, fables, mediaeval romances, exempla, fabliaux, jest-books, and local legends, II, Bloomington, Indiana University Press, 1956), aunque lateralmente cabe añadir también los motivos T 578 " Hombre embarazado », D. 658.3 "Transformación de sexo para seducir », D 10.1 " Solo el ogro tiene poderes para cambiar de sexo con un ser humano " e, incidentemente, D 11 "Transformación de mujer en hombre ".

2. “ Este extraño cuento, con posibles errores de transmisión, guarda estrecha relación con el número 6 ", María Jesús Lacarra (ed.), Sendebar, Madrid, Cátedra, 1995, p. 103.

3. "Nuestro cuento es algo incongruente...", José Fradejas Lebrero, edición modernizada del Sendebar o Libro de los engaños de las mujeres, Madrid, Castalia, 1990, p. 87 (idem en Sendebar, Madrid, Editora Nacional, 1981, p. 99).

4. Por plausible que sea e incluso por necesaria que pueda parecer en algunos casos, la hipótesis del texto defectuoso $o$, lo que viene a ser lo mismo, del copista incompetente no justifica el que se renuncie a una lectura razonada del texto. Que el Sendebar ha llegado hasta nosotros en una versión ostensiblemente deturpada, lo vemos ya desde las primeras páginas del libro a través de las insuficiencias sintácticas del discurso prologal. Pero de ahí a tildar de incoherente cuanto se le escapa al lector moderno, media un trecho que la prudencia incita a no franquear sin previo examen de los datos de que disponemos. Si bien no puede negarse que algunos cuentos de la colección resultan más inmediatamente comprensibles que otros, aparentemente truncos o inconexos, es subterfugio fácil y abuso desconsiderado hacer responsable de todas las incoherencias del texto al copista, máxime cuando en esas supuestas incoherencias, achacadas -a veces prematuramente- a la transmisión defectuosa del texto, puede radicar precisamente el orden profundo del discurso.

5. Agradezco a François Lopez, responsable del programa hispano-francés de investigación "Bibliothèques d'écrivains espagnols à l'époque moderne " y a la agencia ministerial francesa encargada de su gestión material la ayuda facilitada para la realización del presente trabajo. 
alevosamente en medio del bosque, junto a una fuente encantada que avía tal virtud que cualquier omne que beviese d'ella que luego se tornava muger. Ante los requerimientos del rey, que lo ve regresar sin su hijo, el valido pretexta que el infante ha sido víctima de las bestias salvajes del bosque. Solo y cansado de esperar en vano el regreso del valido traidor, el infante decide refrescarse en la fuente, de cuyos efectos mágicos no sospecha hasta que, al beber de ella, queda convertido en mujer. A esta primera intervención maravillosa se añade otra, en la segunda parte del cuento, con la irrupción, ante los ojos todavía atónitos del príncipe recién metamorfoseado en dueña, de un personaje no menos sobrenatural : el diabló. En este punto del relato y hasta el desenlace, la comprensión de la intriga, que se complica notablemente con una sucesión de acciones aparentemente deshilvanadas, se hace más dificultosa, por lo que nos limitaremos a transcribir aquí, hasta su resolución final, la segunda parte del exemplum ${ }^{7}$ :

E quando vio el Infante que tardava el privado e que non tornava por él, desçendió a la fuente a lavar las manos e la cara, e bevió del agua, e fízose muger; e estuvo en guisa que non sabía qué fazer nin qué dezir nin dó ir. E a esto llegó a él un diablo e dixo que quién era él, e él le dixo :-Fijo de un rey de fulana ${ }^{8}$ tierra.

E díxole el nombre derecho e contól"y la falsedat que le fiziera el privado de su padre. E el diablo ovo piedat d'él porque era tan fermoso, e díxole :-Tornarme he yo dueña, commo tú eres, e a cabo de quatro meses, tornarme he commo dantes era.

E el infante lo oy6, e fizieron pleito, e fue $\mathrm{y}^{10}$ el diablo.

Otrosí vino en lugar de muger preñada, e dixo el diablo :-Amigo, tórnate commo dante, e yo tornarme he commo ante era.

E dixo el infante : $-i$ Cómmo me tornaré yo así que, quando yo te fiz' ${ }^{\prime \prime}$ pleito e omenaje yo era doncella e virgen, e tú eres ahora muger preñada?

E estonçes se razonó el Infante con el diablo ante sus alcalles, e fallaron por derecho que vençiera el Infante al diablo. Estonçes se tornó el Infante omne, e fuese para su muger e' levóla para casa de su padre, e contógelo todo commo le acaesçiera. E el rey mandó matar al privado porque dexara al Infante en la fuente.

¿Por qué cambia de sexo el diablo? ¿A qué corresponde el plazo de cuatro meses ? ¿ Cómo interpretar el embarazo del diablo ? ¿ Por qué la intervención final de los alcalles? Las interrogantes se multiplican sin merma aparente de la eficacia persuasiva del exemplum ya que, acabada la narración del cuento

6. Sobre el diablo, su función y sus atributos en la cuentística tradicional, véase especialmente Stith Thompson, El cuento folkórico, Caracas, Ediciones de la Universidad Central de Venezuela, 1972, p. 72-76 (trad. esp. de The Folktale, New York, 1946).

7. Seguimos la edición de María Jesús Lacarra (op. cit., p. 102-103), fiel al texto primitivo (= A), e indicamos en nota las variantes que, en el pasaje transcrito, of rece el texto enmendado por el anónimo lector del siglo $X V(=B)$. Sobre las variantes ortográficas, léxicas y estilísticas entre los textos $A$ y $B$, véase John Esten Keller, "Some stylistic and conceptual differences in texts A and B of El libro de los engaños ". Studia Hispanica in honorem R. Lape'sa, Il, Madrid, Gredos, 1972, p. 275-282.

8. B corrige tal.

9. B corrige dixole.

10. B corrige ay. John Estern Keller, cuya edición se basa en A (Madrid, Castalia, 1959, p. 26), transcribe : E el ynfante lo oyo, e fizieron pleyto, e fue; y el diablo otrosi zino en lugar de muger preñada. La misma lección adopta sin embargo Ángel González Palencia, quien sigue en su edición las variantes de B (Versiones castellanas del "Sendebar ", CSIC, Madrid-Granada, 1946, p. 29).

11. B corrige fize. 
y de vuelta al relato marco, el rey Alcos, convencido de la falsedad de los validos, pronunciará la sentencia ritual condenando a muerte al infante : E el Rey mandó matar su fijo.

\section{Trans(t)ex(t)ualidad y ficción.}

Puesto en boca de la madrastra, el cuento, singularmente representativo de la empresa de descalificación acometida a lo largo del pleito por la infiel esposa contra los validos del rey, ocupa una posición cardinal dentro del libro puesto que, de los cinco cuentos narrados por ella, éste ocupa precisamente la posición central. Otro cuento de la colección, el titulado Striges, narrado inmediatamente antes por la mujer (cuento número 6), merece mención especial aquí por presentar, dentro del ciclo narrativo de la « acusación », la doble particularidad de arrancar de un planteamiento casi idéntico al de Fontes y de hacer intervenir a una diablesa, réplica anticipada del diablo transexual del cuento siguiente. Como en Fontes, la malévola intención del privado queda patente ya desde el comienzo del relato, denunciada aquí por la construcción factitiva fizo [el privado] en guisa que [el infante] fuese a su padre $e$ pidiese liçençia que les dexase ir de caça ${ }^{12}$ : siguiendo el rastro de un venado ${ }^{13}$, el valido abandonará también a su suerte al infante en medio del bosque donde, perdido, se encontrará con ui ra niña que resultará ser una diablesa, a la que desenmascarará al sorprenderla en pleno conciliábulo con sus cofrades y de la que se librará invocando el nombre de Dios. La relación que, desde el punto de vista argumental, guardan los cuentos 6 y 8 del Sendebar no puede ser más estrecha ${ }^{14}$, empezando, como acertadamente apunta María Jesús Lacarra, por el hecho de que ambos « presentan a un infante engañado por una intervención sobrenatural que sólo se anula con otra similar ${ }^{15}$ ». Pero los dos cuentos se presentan, además, uno como imagen invertida de otro, de modo que no sólo pueden establecerse correspondencias sintácticas casi exactas de palabra a palabra entre los dos textos ${ }^{16}$, sino que los personajes de

12. No lo ve así M. J. Lacarra, según quien « frente a lo ocurrido en el núm. 6, aquí [en el núm. 8] queda mucho más clara la intención del privado de engañar tanto al Infante como al Rey " (op. cit., p. 104).

13. El motivo del cazador de ciervos (o de cervatillos) y del encuentro fortuito en medio del bosque ha sido ampliamente estudiado por M. B. Ogle en "The stag-messenger episode ", American journal of Philology, XXXVII, 4, núm. 148, 1916, p. 387-416. Poniendo en tela de juicio la procedencia céltica de estos motivos, el autor destaca una serie de puntos cumunes entre las diferentes historias que, dentro de la tradición occidental, se valen de ellos: " 1 . The hero with his companions and dogs goes out to hunt [...]. 2. His going is entirely upon his own initiative, as far as he knows, and the hunt is nothing but a hunt, not a quest after any particular animal undertaken at the command or upon the challenge of some one else. 3. A stag (hind) starts up before him, and in his eager pursuit of it, he is separated from his companions and is led into a forest, or to some region unknown to him $[\ldots]$, where the animal disappears unhurt. 4. The hero, either immediately, or after further wandering, finds himself in the presence of a beautiful maiden with whom he at once falls in love " (p. 395-6).

14. Cf. M. B. Ogle, art. cit., p. 413 y s.

15. Cuentistica medieval en España : los orígenes, Departamento de Literatura Española, Universidad de Zaragoza, 1979, p. 83.

16. «E el niño fue en pos del venado, atanto que se perdió de su compaña » (6) -.-> « e así fablando uno con otro alongáronse mucho de su compaña " (8); " e yendo así falló una senda, e ençima de la senda..." (6) ---> « E falló él la carrera andándola a buscar e fuese por ella " (8) ; « e el niño dixo : - ¿ Quién eres tú ? E la moça dixo:- Yo so fija de un rey de fulana tierra " (6) ---> « e dixo que quién era él, e él le dixo: -Fijo de un rey de fulana tierra " (8) ; « E el niño ovo duelo d'ella » (6) ---> «E el diablo ovo piedad d'él " (8). 
los dos cuentos aparecen como ediciones diferentes, una en positivo otra en negativo, del mismo sujeto actancial : invirtiendo o, más exactamente, cruzando la relación " infante cazador / infante enamorado » y « niña diablesa / hombre diablo ", observamos que el infante de Fontes, convertido en indefensa doncella, se corresponde no con el infante de Striges sino con la indefensa niña perdida en el bosque y que el diablo de Fontes que se apiada del infante (...ovo piedad d'él) tiene como correlato no al diablo de Striges sino al propio infante que se apiada de la diablesa (...ovo duelo d'ella).

Varios son los descendientes del Libro de Sindibad ${ }^{17}$ que incluyen entre sus cuentos variantes de la leyenda de la fuente mágica, empezando por el Mischlé Sendebar ( Parábolas de Sendebar »), versión hebrea del libro, que lo recoge refundiéndolo significativamente con el cuento de la niña-diablo, lo que subraya aún más la relación entre los cuentos 6 y 8 del Sendebar. Su brevedad nos permite transcribirlo íntegramente aquí :

Huyó él por el campo. Estaba sediento y alzando los ojos vio una fuente en la que cuando alguien bebía si era hembra se volvía macho y si era macho se tornaba hembra. Más él no lo sabía y bebió de la fuente. Se convirtió en hembra. Observó y he aquí que había unas jóvenes danzando y divirtiéndose. Se dispuso a recrearse con ellas, pues se dijo : "También yo me he hecho diablesa ". Las jóvenes le interrogaron diciendo:

- ¿Quién eres?, ¿ de dónde vienes?

Les contó todo lo que le había sucedido y una de las doncellas le dijo :

- Júrame que me tomarás como esposa si te salvo y te devuelvo a tu padre. Se lo juró y ella añadió :

- Bebe de la fuente y serás macho como al principio. Lo tomó consigo la muchacha y lo llevó a la casa de su padre. Contó el príncipe a su padre todo lo que le había ocurrido's.

El instrumento de la desgracia coincide aquí con el instrumento de la salvación : la fuente, responsable del cambio de sexo del protagonista, será la que lo devuelva a su ser original. El desenlace del cuento (impensable en el Sendebar, pues el infante se casa aquí con una de las jóvenes del bosque) se

17. Para un estudio pormenorizado de la genealogía del libro así como para la composición de sus diferentes descendientes, véanse Bernard Darbord, "Le roman des Sept sages. Etude d'une tradition en Espagne ", Aux origines du conte en Espagne : "Calila e Dimna ", "Sendebar ", Université Paris X-Nanterre, Centre de Recherches Ibériques et Latino-Américaines, 1996, p. 25-60, Ventura de la Torre, "Filiación de las versiones castellanas del ciclo Siete Sabios de Roma. Variantes del Sendebar occidental », RFE, 72 , 1992, p. 103-115, así como el indispensable trabajo de A. Loiseleur Deslonchamps, Essai sur les fables indiennes et sur leur introduction en Europe, I'aris, Techener, 1938, p. 80-180. Señalaremos asimismo el estudio de Bonnie Diane Irwin Lotfizadeh, "The book of Sindibad " and "The sezen sages of Rome": perspectives on the frame and its relationship to the interpolated tales in the Persian, Arabic, Latin, and Spanish versions, Michigan, UMI, Dissertation Information Services, 1993, tesis doctoral que no nos ha sido posible consultar.

18. Los cuentos de Sendebar, edición, traducción y notas de Ángeles Navarro Peiró, Sabadell, Editorial Ausa, Orientalia Barcinonensia, 1988, p. 66-67. Apenas si se aprecian ligeras variantes en la versión latina de la Historia septem sapientum I, 6 : « Et venit ad quendam fontem, de quo quicumque bibebat si masculus erat vertebatur in feminam, et si femina erat vertebatur in masculum. Et ipse nesciebat, sed bibit, et versus est in feminam et cepit lacrimari et timebat adhuc bibcre de aqua. Et ipse mestus mansit in illa nocte ibi, et ecce turba puellarum venit et ludebant et cantabant juxta fontem. Surrexit etiam ipse ad ludendum cum eis, quia credebat se factum esse strigam. Interrogaverunt eum puelle et dixerunt : Qui es tu et unde venis? Ipse autem narravit omnia qui acciderant sibi. Cui una illarum dixit : Jura mihi 
explica por las divergencias que presenta el planteamiento de los dos relatos: el joven noble, que no está prometido a ninguna princesa, sale en compañía del consejero con el mero pretexto de ir de caza.

Asimismo cabe mencionar, entre las versiones árabes de la leyenda, la incluida en el libro de los Siete visires, íntegramente recogido en las Mil y una noches. El planteamiento de la acción es análogo al de nuestro texto, con la diferencia de que el ministro actúa a instancias de un envidioso primo del infante, pretendiente desdeñado de la princesa :

El hijo del rey desmontó, se lavó las manos, bebió, y quedó convertido en mujer. Cuando se dio cuenta de ello se puso a gritar y a llorar hasta que se desmayó [...] Durante tres días y tres noches el hijo del rey permaneció junto a aquella fuente, sin comer ni beber [...] La cuarta se presentó ante él un caballero [...] El joven le contó lo ocurrido [...] Cuando el caballero hubo escuchado sus palabras, se compadeció de su situación ${ }^{19}$ y le dijo [...] : "Cuando salgas de tu enfermedad, volverás junto a tu familia más de prisa que en un abrir y cerrar de ojos : esto es cosa sencilla para $\mathrm{mi}^{2}$ " ".

Pero ambos relatos difieren notablemente tanto por su extensión (dilatada y amplificada en los Siete visires por la multiplicación de peripecias y por la minucia descriptiva del narrador) como por su desarrollo. Efectivamente, una vez convertido en mujer, el hijo del rey emprende aquí un viaje iniciático de varios días en compañía del misterioso caballero, hijo del rey de los genios, quien lo conducirá hasta la Tierra Negra, " pedazo de infierno " donde se encuentra la Fuente de las Mujeres cuya agua transforma en hombre a la mujer que la bebe. Tras recobrar así su apariencia inicial, un efrit-genio islámico entre ángel y demonio-lo llevará volando hasta el palacio de su suegro, donde se celebrará la boda y consumará el matrimonio.

Si el motivo de la fuente mágica aparece como una constante en todos estos relatos y el desenlace de la acción conduce invariablemente al restablecimiento de la situación inicial, el nudo de la intriga, como puede verse, varía sensiblemente, pese al indudable parentesco que los vincula genéticamente, de un cuento a otro : ejercida en el relato de los Siete sabios ${ }^{21}$ por un genio benigno, la función del diablo, por ejemplo, se diluye en una pluralidad de personajes en el Mischlé Sendebar (el festivo coro de jóvenes) que incluye al propio príncipe convertido, según él mismo afirma, en «diablesa », y en

quod ducas me uxorem et liberabo te et revocabo ad patrem tuum. Et juravit ei. Et illa : Bibe de aqua fontis illius. Bibit et mutatus est in masculum. Illa autem accepit et reduxit ad patrem suum. Ipse vero retulit patri omnia visa ". Adviértase el empleo, en la versión latina, de la palabra striga -que igualmente da título al cuento en su versión hispánica-, en consonancia con la creencia medieval de que las brujas son originalmente hombres metamorfoseados en mujeres : "quidam adserunt Strigas ex hominibus fieri ", explica Isidoro de Sevilla (Etimologías, XI, 4, 2). Desarrollamos estas cuestiones más adelante (cf. infra § II, 3).

19. Obsérvese que la reacción del caballero compadeciéndose de la situación del príncipe coincide con la del diablo de nuestro cuento, "que ovo piedad d'él ".

20. Ias mil y una noche's, II, Traducción, introducción y notas de Juan Vernet, Barcelona, Planeta, 1990, noches 582 y 583, p. 311 y s.

21. Recientemente reeditado por Ventura de la Torre (Madrid, Miraguano, 1993). 
ninguno de los dos cuentos el cambio de sexo del protagonista va acompañado, como ocurre en Fontes, del cambio de sexo del personaje auxiliar. Convertido por arte de magia en dueña, el diablo de nuestro cuento es, de alguna manera, objeto de una segunda mutación, natural ésta, que lo convierte en muger preñada. Ser proteico por excelencia, el diablo es capaz de adoptar todas las formas posibles -humanas, celestes y animales-, ya que, como explica Rameline E. Marsan, " el demonio, en tanto que espíritu del mal, no tiene ni forma material ni, por consiguiente, sexo definido. Sólo la necesidad del momento en el transcurso de sus reencarnaciones determina el sexo de sus transformaciones humanas ${ }^{22}$ ». Esta indiferenciación sexual del diablo y, por extensión en nuestro cuento, el dimorfismo del infante, reviste también implicaciones lingüísticas. En nota a su traducción española arriba reproducida de la versión hebrea del cuento, Ángeles Navarro Peiró comenta a este respecto : «El género gramatical de los nombres, pronombres, verbos, etc. [...] se emplea de un modo confuso, utilizando indistintamente el masculino y el femenino. Según anota Epstein, es posible que el redactor del texto hebreo jugara conscientemente con los géneros gramaticales para transmitir al lector la confusión de sexos que en el relato aparece ${ }^{23} »$. El mismo juego puede observarse sin embargo en la versión hispánica del cuento -el diablo conserva invariablemente, a pesar del cambio de sexo, la morfología masculina de su nombre a lo largo de todo el cuento y el narrador, apenas evocada la transformación del infante, insiste en hablarnos de un príncipe hermoso- y lo mismo puede decirse del ya aludido cuento número 6 que, prefigurando este juego de transformaciones sexuales y anunciando también la aparición del diablo en el libro, pone en escena a una diablesa (striga ${ }^{24}$ ), a la que el discurso se refiere haciendo uso indistintamente del género femenino (cuando el infante descubre la impostura, el narrador explica que vio que era diabla) y del género masculino (cuando se encomienda a Dios, exclama pidote por merced que me libres de este diablo ${ }^{25}$ ). A la vez macho y hembra, niña y monstruo, diablo y diabla, el diabólico personaje de Striges, al que Rameline E. Marsan no vacila en hacer heredero de la tradición islámica de los efrits -uno de cuyos representantes acabamos de encontrar en el relato de las Mil y una nochesconfirma así su estatuto dual y fronterizo : «En sus relatos el Islam puede proceder a una especie de transferencia de poderes atribuyendo los poderes y las intenciones de los ángeles o de los demonios a cierto tipo de genios intermedios, los Efrits. En ese caso, el efrit tiene generalmente un sexo y suele ser una efrita, buena o mala, la que aparece bajo su apariencia propia o tomando prestada una forma femenina [...] El caso aislado [en el cuento número 6] de este demonio hembra, de esta "diabla" podría explicarse tal vez por la influencia del texto árabe original, en una versión que está todavía por determinar, en que el

22. "...le démon, en tant qu'esprit du mal, n'a ni forme matérielle, ni sexe par conséquent. Seule la nécessité du moment au cours de ses incarnations détermine lé sexe dé ses métamorphoses humaines ". (La traducción es nuestra). Itinéraire espagnol du conte médiézal (VIII-XV siècles), Paris, Klincksieck, 1974, p. 271-272.

23. Op. cit., p. 67.

24. Cf. supra nota 18.

25. Si bien el uso del término no marcado de la oposición puede remitir aquí al ente genérico. 
papel de diablesa podría haberle sido asignado a una efrita ${ }^{26}$ ". En cualquier caso la correspondencia trans $(t)$ ex $(t) u a l$ entre la striga del cuento 6 y el diablo del cuento 8 es innegable, siendo así que ambos personajes -íncubo y súcubo- no son sino declinaciones específicas e inversas del mismo « archi-personaje ».

\section{Lectura del cuento.}

En cuanto a la intriga propiamente dicha del exemplum que nos ocupa aquí, puede decirse que, si las hipótesis de lectura que permite barajar el cuento son diversas, casi todas encuentran en las escasas quince líneas que componen el fragmento transcrito la prueba que las invalida. Una de ellas es la apuntada por José Fradejas, quien supone que la muger preñada en que se transforma el diablo lo ha sido precisamente por el propio infante. Según el autor, a diferencia del relato incluido en las Mil y una noches, "...nuestro cuento se complica con la burla al diablo, a quien [el infante] deja encinta ${ }^{27}{ }^{\prime}$. Insistiendo en la incoherencia del relato, añade el crítico : «...la conclusión es confusa y no tiene la intencionalidad que la esposa del rey le atribuye. ¿ Cómo es posible que siendo el príncipe y el diablo mujeres, éste quede preñada ? ¿Qué razón hay para el juicio ? ¿ Por qué la conclusión de que el príncipe había vencido al diablo ? Esta parte final no tiene relación con la estructura y pertenece al número de los cuentos : "el diablo burlado", que en el mundo folclórico son abundantísimos y con infinitas variante ${ }^{28} »$. Planteado así el problema, las preguntas que a propósito de su propia hipótesis se hace el autor son, como se puede constatar, la mejor prueba de su inviabilidad ; en efecto, ¿ cómo ha podido dejar embarazada a la diablesa un príncipe del que se nos dice expresamente que acaba de convertirse en doncella? Pero también cabría imaginar que, cuando el diablo regresa junto al príncipe transcurrido el plazo de cuatro meses, los efectos mágicos del agua ya han desaparecido y, por tanto, que el príncipe ha recobrado ya su apariencia normal. Sin desarrollarla explícitamente en el comentario que le dedica al cuento, es ésta también la lección que sigue el propio Fradejas según se desprende claramente de la versión modernizada que propone del texto : «El infante aceptó, hicieron pleito y homenaje y mientras tanto se pasaron los efectos del agua y el diablo se vio como mujer ". Dos secuencias del cuento invalidan sin embargo por completo esta lectura : la primera, la frase tórnate commo dante proferida por el diablo en su segunda aparición, frase incoherente desde esta óptica -ya que no se ve qué sale ganando el infante haciendo pleito con el demonio si, devuelto naturalmente a su apariencia inicial, el diablo lo vuelve a transformar en mujery que el moderno editor, mediante una sorprendente manipulación textual,

26. "L'islam peut dans ses récits procéder à une sorte de transfert de pouvoirs en attribuant les pouvoirs et les intentions des anges ou des démons à des sortes de génies intermédiaires, les Éfrits. Dans ce cas, l'éfrit a généralement un sexe, et c'est souvent une éfrita, bonne ou mauvaise, qui fait son apparition sous son apparence propre ou sous une forme féminine empruntée [...] Le cas isolé de ce démon femelle, de cette "diabla" pourrait peut-être s'expliquer grâce à l'influence du texte arabe original, dans sa version qui n'est pas encore déterminée, dans lequel le rôle de la démone serait attribué à une éfrita " (La traducción es nuestra). Op. cit., p. 272.

27. Op. cit., p. 87.

28. Op. cit., p. 87. 
convierte, alterando los tiempos verbales ${ }^{29}$, en te has tornado como eras antes; la segunda, la frase estonçes se tornó el Infante omne del final del cuento, que implica necesariamente que cuando el infante comparece ante los alcalles tiene apariencia femenina y que Fradejas, esta vez, suprime sin contemplaciones en su edición. Sin necesidad, sin embargo, de suponer que han desaparecido los efectos del agua cuando el diablo regresa, cabría la posibilidad de interpretar literalmente, sin recurrir ni a presuposiciones ni a ningún otro tipo de razonamiento extrapolador, la frase Amigo, tórnate commo dante, e yo tornarme he commo ante era en el sentido de "conviértete otra vez en hombre y vuelva yo a ser hombre también ». Pero en ese caso, ¿ cómo justificar -sin suponer inmediatamente que, satisfecho con su nueva anatomía, el infante desea prolongar su experiencia transexual- la respuesta claramente negativa que, en forma de pregunta, le da el príncipe? ¿Cómmo me tornaré yo así-se inquiere el infante ante la solicitud del diablo- que, quando yo te fiz' pleito e omenaje yo era doncella e virgen, e tú eres ahora muger preñada? E incluso haciendo abstracción de la respuesta del príncipe, ¿ qué sentido tendrían todas estas transformaciones si fuera para acabar restaurando el orden inicial sin que entre el desenlace y el planteamiento del cuento medie el menor conflicto?

El sentido de la oscura réplica del infante se aclara, sin embargo, a la luz que arrojan las escuetas -aunque profusamente documentadas-observaciones que a propósito del cuento hace Aurelio M. Espinosa. Tras un detenido repaso de los diferentes objetos y acciones que, en la tradición cuentística y folclórica, pueden desencadenar el cambio de $\operatorname{sex}^{30}$ (desde la ingestión de agua o de una pastilla, hasta la introducción de una planta o de una píldora por la oreja, pasando por un salto o una caída brutal, la inmersión en el agua de una fuente, de un río o del mar, la contemplación de dos serpientes copulando, la formulación de plegarias o maldiciones, el contacto con un animal o el paso por debajo del arco iris), el autor explica que es el diablo quien, en nuestro cuento, devuelve al infante a su forma primera intercambiando su propio sexo con el de la doncella. Se apoya el erudito autor en la larga tradición oriental, recogida en numerosos cuentos, del intercambio de sexos, uno de cuyos ejemplos más destacables aparece en el Somadeva, VII, 223 del Mahabbarata en que una mujer, a la que los padres hacen pasar por hombre, se casa con una princesa previa intervención de un yaksha -servidor del Dios Kuvela- con quien permuta su sexo. Según Espinosa, el doble cambio de sexo se produce en nuestro cuento « de una manera que recuerda los detalles del Mahabbarata, el diablo haciendo el papel de yaksha ${ }^{31}$ ". Pero ahí se acaba el comentario del

29. No menos sorprendente resulta la modificación a que somete la persona gramatical en otro momento de su libre adaptación: alli donde el texto reza yo era doncella e virgen el autor transpone eras doncella y zirgen.

30. Para la bibliografia anterior a 1885 sobre el cambio de sexo, cf. Victor Chauvin, Bibliographic des ouvrages arabes ou relatifs aux Arabes publiés dans l'Europe chrétienne de 1810 a 1885 , VIII, Liège, H. Vaillant-Carmanne, 1904, p. 43-44 (volumen dedicado al Syntipas). En cuanto a la tradición céltica de este mismo motivo, cabe mencionar aquí el articulo de H. Gaidoz, "Du changement de sexe dans les contes celtiques", Re'tu' de l'histoire des religions, LVII, 1908, p. 317-332 (traducción y estudio de un cuento irlandés en el que el cambio de sexo sobreviene durante el sueño).

31. Aurelio M. Espinosa, Cuentos populares españoles, III, Madrid, CSIC-Instituto Antonio de Nebrija, 1947, p. 105. 
autor, que se limita a reproducir, sin detenerse a explicar los pormenores de la intriga, el texto correspondiente a esta parte del relato. Atendiendo a estos datos, podría glosarse la historia del siguiente modo : apiadándose del infante, el diablo le propone intercambiar su sexo con el de la doncella en que ha quedado convertido durante un período de cuatro meses, transcurridos los cuales cada personaje volverá a transformarse en lo que era antes (la diabla en diablo, el infante en doncella). Cumplido el plazo, el diablo regresa en lugar de muger preñada junto al infante para que le devuelva "lo" que le ha dado (Amigo, tórnate commo dante, e yo tornarme he commo ante era), pero comprendiendo que aceptar un nuevo intercambio de anatomías supondría no sólo renunciar a su recobrada masculinidad sino, además, encontrarse encinta, el infante le contesta negativamente ( ¿ Cómmo me tornaré yo así que, quando yo te fiz' pleito $e$ omenaje yo era doncella $e$ virgen, $e$ tú eres ahora muger preñada?) : de ahí la necesidad de apelar a los alcalles para que arbitren el litigio.

\section{La palabra y la acción.}

Pese al innegable hallazgo interpretativo que supone la lectura de Espinosa, quedan por resolver dos puntos a primera vista contradictorios con la argumentación expuesta : 1) si ha habido intercambio de sexos entre el infantedoncella y el diablo, esto quiere decir que, en el instante en que el diablo toma la identidad sexual de la mujer, el infante usurpa recíprocamente la del diablo, lo que sólo puede concebirse si se postulan una serie de transformaciones intermedias silenciadas por el narrador, ya que el desenlace del cuento parece indicar que el infante no vuelve a ser hombre hasta acabado el juicio : Estonçes se tornó el Infante omne, e fuese para su muger ; 2) aun admitiendo esta hipótesis, resulta incomprensible que el infante, devuelto ya a su forma primigenia, permanezca, como hace aquí, cuatro meses en el bosque cuando nada le impide ya reunirse con su prometida.

Los escollos con que tropieza la lectura se despejan sin embargo por poco que se atienda a la literalidad del texto, en realidad mucho menos incongruente de lo que tradicionalmente ha venido afirmándose. El primer obstáculo se desvanece si se atiende a la configuración ilocutiva del discurso, en el que convergen, claramente disociados, dos tipos de enunciados diferentes, constativos unos y performativos otros. Exclusivamente reservado al diablo, este último tipo de enunciado, en que palabra y acción, logos y ergon, se confunden en un mismo y único acto de habla, aparece invariablemente en discurso directo, en contraste con el discurso transpuesto que domina la casi totalidad del texto. Nombrando una acción el diablo hace mucho más que designar un proceso : hace que se cumpla. Del carácter performativo de su discurso da cuenta la actitud del narrador que, tras reproducir la frase tornarme he yo dueña, commo tú eres... asertada por el diablo en su primera intervención, no considera necesario añadir ...y el diablo se convirtió en dueña para explicitar el cumplimiento del proceso. De ahí que tampoco lo haga en la segunda intervención oral del diablo : cuando, transcurridos los cuatro 
meses del plazo fijado, el diablo le dice al infante tórnate commo dante, e yo tornarme he commo ante era, no está simplemente intimándole una orden a la que el infante podrá libremente someterse o sustraerse ; está ejecutando ya el proceso mismo que declara. En efecto, no es el infante, sino el diablo quien está investido de poderes sobrenaturales : incapaz de desactivar el proceso puesto en marcha por el diablo, la respuesta del infante, si bien expresa el rechazo del personaje ante la perspectiva de verse convertido en mujer embarazada, no tiene incidencia alguna en el curso de los acontecimientos. Sucesivamente transformado en mujer por la fuente y en hombre por el diablo, el infante comparece, pues, convertido una vez más en mujer ante los jueces, quienes dictaminando en su favor harán posible su transformación final y definitiva en hombre: Estonçes se tornó el Infante omne, e fuese para su muger.

En cuanto a la segunda dificultad señalada ( $i$ por qué espera el infante el retorno del diablo si ha recobrado ya su masculinidad ?), el texto proporciona una vez más las claves necesarias para su elucidación. Un aspecto que no se ha tenido suficientemente en cuenta hasta aquí y que resulta fundamental para la cabal interpretación del texto es la resolución jurídica del cuento, que desarrolla así una intriga paralela en forma de debate $o$, por emplear la palabra que aparece en el texto, de "razón" y que, reproduciendo a escala inferior el proceso jurídico que en el relato marco enfrenta al infante (representado por los validos) con la esposa traidora, nos pone inmediatamente en presencia de lo que, dentro de la tipología de las formas narrativas simples, André Jolles llama «caso" (Kasus), en el sentido judicial del término ${ }^{32}$. El vocabulario jurídico que invade el discurso (pleito, omenaje, razonó, alcalles, fallaron por derecho, venciera) nos invita, pues, a reflexionar sobre los términos del contrato (pleito) convenido entre el diablo y el infante. Todo pacto se basa en un principio de reciprocidad y supone por tanto derechos y deberes, es decir, ventajas y contrapartidas para las dos partes. Así, lo que estipula el pacto -anulado por los jueces al final del relato- es un trueque de sexos temporal : el diablo le devuelve al infante su forma primera por un periodo de cuatro meses, a cambio de que, en su momento, éste acceda a devolverle a aquél su sexo original, lo que, no siendo el infante ni hechicero ni taumaturgo, vale tanto como decir a cambio de la promesa firme de que acudirá al lugar el día señalado. En suma, lo que hace el infante mediante este omenaje es darle garantía al diablo de que no se escapará. En efecto, la institución jurídica del homenaje es a la vez promesa de servidumbre y obligación de lealtad : si el infante no huye del bosque es porque está sujeto por una promesa -palabra hecha acción- a la que la dignidad moral de su rango y la probidad de su persona le prohiben faltar. La incoherencia del relato, si es que de incoherencia puede hablarse, no estriba pues en lo supuestamente deshilvanado de su argumento, como se ve perfectamente elaborado, sino en lo argumentativamente inadaptado de su concepción con respecto a los objetivos perseguidos por su conceptora, ya que el infante al que la madrastra pretende desacreditar y condenar a muerte sale engrandecido de su ejemplo, recompensado por su lealtad y victorioso ante la justicia. 
Completando los silencios del texto y a modo de conclusión, se podría resumir la lectura propuesta de la siguiente manera :

E díxole el nombre derecho e contól' la falsedat que le fiziera el privado de su padre. E el diablo ovo piedat d'él porque era tan fermoso, e díxole :-Tornarme he yo dueña, commo tú eres, para que tú puedas recobrar tu apariencia de hombre e a cabo de quatro meses, tornarme he commo dantes era y tú volverás a ser mujer.

E el infante lo oyó, e fizieron pleito dándole el infante su palabra de que estaría allí el día convenido, e fue y el diablo.

Otrosí vino en lugar de muger preñada, e dixo el diablo:-Amigo, tórnate mujer commo dante, e yo tornarme he hombre commo ante era.

E dixo el infante : - ¿Cómmo me tornaré yo así que, quando yo te fiz' pleito e omenaje yo era doncella e virgen, e tú eres ahora muger preñada? Si volvemos a intercambiarnos nuestros sexos seré yo quien esté embarazada.

E estonçes no conforme con la nueva situación se razonó el Infante convertido de nuevo en mujer con el diablo devuelto a su forma masculina ante sus alcalles, e fallaron por derecho que vençiera el Infante al diablo anulando asi el pacto que lo unía a éste. Estonçes se torn 6 el Infante omne, e fuese para su muger e levóla para casa de su padre...

\section{DEL CUENTO A LA ARQUITECTURA DEL LIBRO}

...le récit est, par une astuce vertigineuse, la représentation du contrat qui le fonde : dans ces récits exemplaires, la narration est théorie (économique) de la narration : on ne raconte pas pour "distraire", pour "instruire" ou pour satisfaire un certain exercice anthropologique du sens; on raconte pour obtenir en échangeant; et c'est cet échange qui est figuré dans le récit lui-même : le récit est à la fois produit et production, marchandise et commerce, enjeu et porteur de cet enjeu...

Roland Barthes, S/Z, XXXVIII.

Existe en el Sendebar un tercer cuento, Del enxemplo de la diableza e del omne $e$ de la muger, e de cómmo el omne demandó los tres dones, recogido bajo el título Nomina (número 17), en que, al igual que sucede en Striges y en Fontes, interviene una diabla. Narrado por el séptimo privado para ilustrar los engaños de las mujeres, el texto recoge el motivo de los tres deseos mágicos, concedidos aquí por una diableza y malgastados tontamente por su beneficiario. El cuento engarza con los dos exempla citados tanto por la presencia de este personaje como por la configuración de la ficción narrativa, centrada también en la palabra y en su poder realizativo. Considerados conjuntamente, puede incluso decirse que Nomina y Striges están en relación de simetría inversa : si en Striges el infante se deshace de la diabla por medio de la palabra, en Nomina es la diabla quien parece tomar la revancha concediéndole al protagonista, a modo de regalo envenenado, tres deseos que -acto performativo por excelencia- se cumplirán con sólo formularlos, pero que el hombre echará a perder por seguir los consejos de su esposa.

A la vista, por una parte, de las correspondencias que pueden establecerse entre los dos cuentos de la acusación, Striges y Fontes, y el cuento de la defensa, Nomina, que parecen formar dentro del libro una especie de tríptico (diabla- 
diableza-diablo), esto es, un ciclo narrativo completo, y, por otro, de la posición que ocupan los dos primeros, entre los que excepcionalmente no media sino un relato, arriesgaríamos aquí la hipótesis de que el cuento de la colección que se ha supuesto perdido por errores de transmisión (el segundo exemplum del tercer privado, que sólo cuenta uno de los dos cuentos que cada privado está autorizado a narrar) no es otro que el cuento Nomina que, habitualmente reproducido en decimoséptima posición, podría haber sufrido un corrimiento desde la octava. Así considerado, el cuento Nomina constituiría la respuesta que da el tercer privado a la segunda intervención de la mujer (con el cuento Striges), por lo que cabría formular la hipótesis de que el relato que realmente falta no es el segundo del tercer privado-desplazado dentro del libro, pero no perdido-, sino el primero del séptimo privado. Puesto en boca del tercer privado, el cuento se encontraría enmarcado precisamente entre Striges y Fontes, completando así el paradigma narrativo dedicado al personaje del diablo. Si bien el cambio de posición no modifica sustancialmente aquí ni el contenido del cuento ni su funcionalidad, no puede pasarse por alto la importancia que cobra, en el proceso de semantización del discurso ejemplar, la ubicación de cada cuento dentro del relato marco ${ }^{33}$, como demuestra el que un mismo exemplum, contado en el Sendebar para inocentar al infante, pueda en otras versiones del libro servir, en boca de la acusación, para incriminarlo ${ }^{34}$. En cualquier caso, los indicios textuales que concurren a favor del desplazamiento del cuento son varios, empezando por la rigurosa estructuración del libro y por la presencia de numerosas conexiones internas (cuentos que se contestan, se prologan unos a otros o se oponen formando series), que confirman que el ordenamiento de los cuentos homofuncionales, esto es, pertenecientes al mismo grupo narrativo, no es aleatorio, sino que, fruto de una clara voluntad arquitectónica, responde a un proyecto narrativo premeditado -como deja patente la constante reflexión que sobre su propio quehacer nutre la escritura a lo largo del libro-, sin olvidar una serie de

33. En nuestro estudio sobre la poética del ejemplo en el Calila é Dimna apuntábamos a este respecto : "Affirmer, comme le fait Barthes, que l'exemple est un "morceau détachable qui comporte expressément un sens" et faire de cette propriété sa "vocation structurale", c'est oublier que l'exemple est toujours exemple de quelque chose, que sa motivation est extérieure à lui-même, qu'il n'est en somme qu'une étape, un moment de l'argumentation. Loin d'apporter la preuve de son autonomie, le fait que l'exemplum puisse être "détaché" démontre tout au plus que l'exemple, qui est toujours le produit d'une manipulation, peut lui-mème être manipulé, c'est-à-dire artificiellement retiré et amputé du contexte qui tout à la fois l'amène, le fonde et lui confère, dans le cadre d'un raisonnement donné, un sens ou du moins un horizon interprétatif spécifique. Ce conflit qui met aux prises, d'unè part, l'intransitivité du récit se donnant à lire comme une fiction indépendante et, d'autre part, sa transitivité, c'est-à-dire l'extériorité et l'antériorité de son objet -ce que certains auteurs appellent "l'intentionnalité" -, spécific le statut paradoxal de l'exemple : il ést récit ét en tant que récit il 'st doté d'une" autonomie qu'il perd en tant qu'exemple" "Poétique de l'exemple. Notes sur le livre de Calila é Dimna", Lés langues néo-latinés, 296, 1996, p. 19-20. Véase igualmente el excelente estudio de Georg Bossong "Sémantique et structures textuelles dans le livre de Calila it Dimna. Essai de thécrie textuelle appliquée ", Cahiers de linguistique hispanique médiérale, 9, 1979, p. 173-203, y el ya clásico estudio de Claude Bremond, Jacques Le Cioff y Jean-Claude Schmitt, $L^{\prime}$ ' 'xe'mplum ", Turnhout-Bélgica, Brepols, 1982, especialmente los capítulos dedicados a la descomposición sintagmática del exemplum (p. 113131) y al exemplum en la retórica del sermón (p. 154-164).

34. Es, como oportunamente señala Bernard Darbord (op. cit., p. 37), lo que ocurre con el cuento Senescalcus: puesto en boca de la defensa para incitar al rey a mayor reflexión antes de condenar precipitadamente al infante, aparece en la Scala coeli de Johannes (jobi en boca de la madrastra para acusar al infante y a los privados. 
indicios formales que denuncian el desenclavamiento de que ha sido objeto el cuento. Centrándonos en el análisis de estos aspectos, trataremos de argumentar, a continuación, la hipótesis propuesta.

\section{El organigrama narrativo.}

El libro consta de veintitrés cuentos rigurosamente repartidos en tres grupos : los cinco cuentos de la madrastra, los trece cuentos de los siete validos y los cinco cuentos narrados por el propio infante al final del libro. Las seis intervenciones de la mujer (cinco cuentos, más una escena contada por un narrador extradiegético, pero protagonizada por ella) segmentan los exempla de los validos en siete grupos de dos, salvaguardando así la simetría -aunque no la proporción-entre las intervenciones de la defensa y las de la acusación ${ }^{35}$. De los cuentos narrados por la mujer, nos limitaremos a señalar aquí que el orden en que se encuentran dispuestos no es arbitrario, como refleja la gradación que conduce de la acusación del infante a la incriminación de todos los validos y de la argumentación mediante ejemplos a la intimidación mediante amenazas. El primer cuento (Lavator) tiene una función claramente introductoria, pues es el único de la serie que se centra en el personaje del infante : mediante una ficción embrionaria, por no decir raquítica, y con una novelización mínima de la sentencia que pretende ilustrar ${ }^{36}$, el cuento advierte al rey de los peligros a que se expone queriendo salvar a su hijo. Más elaborados, los cuatro cuentos siguientes (Striges, Fontes, Aper y Simia) suponen un cambio de estrategia argumentativa, pues, todos ellos incriminan directamente a los privados, a los que la narradora convierte en blanco exclusivo de sus invectivas. Por último, la intervención final de la mujer declara el fracaso definitivo de la palabra y de su poder persuasivo, anunciado ya por las diferentes amenazas de suicidio proferidas por ésta : como si la palabra sola ya no bastara, la madrastra se siente movida a pasar al acto intentando quitarse la vida.

35. El principio matemático y, puede decirse también, geométrico por que está regido el libro en su totalidad pone en relación de perfecta equivalencia la acción de contar y la de computar : a la vez que "cuenta » el proceso jurídico, el narrador principal «lleva la cuenta " de las intervenciones de uno y otro narrador secundario.

36. Frente a la inventiva de que hará gala en los cuentos sucesivos, el primer relato de la madrastra -reducido a la mínima expresión-es, hasta cierto punto, la negación misma del ejemplo : para ilustrar los riesgos que amenazan al padre por culpa de su hijo, el cuento refiere, en seis líneas escasas y de manera casi tautológica, la muerte de otro padre en su intento por salvar a su hijo. La ejemplificación del segundo cuento de la madrastra (Striges), si bien más compleja que la del anterior, arranca también de una transposición ficcional que, próxima al grado cero, resulta igualmente tautológica (« $A$ es como $A$ ", en lugar de « $A$ es como $B$ ") : "Señor, estos tus privados son malos e matarte an, así commo mató un prizido a un re'y una vez " (p. 96), lo que vale tanto como decir que los privados malos son como los privados malos y que el rey es como el rey... Contrasta esta actitud con la progresiva amnesia de la narradora que, alejándose paulatinamente de su propósito inicial, acaba aduciendo una argumentación retóricamente " contraproducente" (es difícil no ver en la relación infante-diabla del cuento la proyección de la pareja infante-madrastra del relato marco). En otro orden de ideas, aunque a propósito de este mismo incipit, M. J. Lacarra subraya en su edición la inexactitud del anuncio hecho por la narradora, « pues el privado del cuento no matará a ningún rey » (p. 96). En realidad, se trata de un falso problema : desde los orígenes del idioma, está atestiguado el empleo del verbo matar en el sentido de 'herir' y, figuradamente, en el sentido lato de 'afligir', 'apesadumbrar', etc. A nadie extraña que frases como "Este calor me mata " o "Me mato trabajando para nada " no vayan seguidas del fallecimiento de quien las profiere. ¿ Por qué no había de tratarse aquí del mismo empleo traslaticio? 
Por su parte, los cuentos de los privados responden, como es sabido, a una doble estrategia : el primer cuento narrado por cada privado pretende inocentar al infante ${ }^{37}$, mientras que el segundo, de carácter marcadamente, misógino, pretende acusar a la madrastra, de modo que cabe considerar cada pareja de cuentos no como dos demostraciones independientes, sino como dos etapas de una sola y única demostración a cargo del mismo orador o, lo que es lo mismo, como una misma demostración efectuada en dos tiempos. Si consideramos el segundo bloque de cuentos observamos que, construidos según el mismo esquema argumental, todos tienen como protagonista a una mujer adúltera. En todos ellos la mujer engaña dos veces al marido : siéndole infiel primero al cometer o al aceptar el adulterio, y mintiéndole después al concebir una estratagema para disimular su engaño. La ilustración de los engaños de las mujeres culmina en el último cuento de la serie (Ingenia), donde la astucia de la mujer es tal que cometiendo el adulterio consigue burlar no ya al marido sino al propio amante. El título latino de todos estos cuentos remite invariablemente al instrumento -a la vez arma y móvil-de que se vale la mujer para perpetrar el engaño y en todos los cuentos el hombre queda ridiculizado en el desenlace ya que, no contento con reconciliarse con la mujer, acaba pidiéndole perdón ${ }^{38}$, cuando no felicitándola (Gladius) o recompensándola (Canicula). En dos casos (Canicula y Pallium) la culpabilidad de la mujer se desdobla actancialmente en dos personajes a la vez opuestos y complementarios : la esposa y la alcahueta. Todo lo cual puede resumirse del siguiente modo :

Avis Mujer : adúltera. Instrumento del engaño : un papagayo ${ }^{34}$. Desenlace : marido y mujer se reconcilian.

Gladius Mujer : adúltera por partida doble (engaña al marido con su amante y al amante con un criado de éste).

Instrumento del engaño : una espada ${ }^{411}$.

Desenlace : el marido felicita a su mujer.

Canicula Mujer : hay dos : la esposa, dispuesta a cometer el adulterio (aunque no llegue a consumarse), y la alcahueta que lo prepara.

Instrumento del engaño : una perrita.

Desenlace : el marido le pide perdón a la esposa adúltera, quien sólo aceptará sus disculpas a cambio de un regalo; el marido le hace donación de una aldea.

37. En realidad no se trata tanto de inocentar al infante como de intimidar al rey culpabilizándolo. En cualquier caso, se hace patente el desplazamiento y progresivo olvido del móvil narrativo, el proceso contra el infante, que, muy rápidamente, se verá relegado por otro proceso : el que se hace contra las mujeres. A lo largo del juicio, la defensa no hace sino acusar a la mujer, quien a su vez no hace sino acusar a la defensa, de modo que el infante y el delito que se le achaca caen completamente en el olvido. Y es que el discurso didáctico está aquí puesto al servicio de otra causa : no es el infante quien, en realidad, está en el banquillo de los acusados, sino la mujer.

38. Comportamiento que no deja de recordar al del "Carpintero engañado por su mujer " del capítulo VI del Calila e Dimna.

39. Nótese el doble estatuto del ave, que es a la vez el indicio que delata a la esposa adúltera y el instrumento de que se sirve para disipar las sospechas que pesan sobre ella. Véase más abajo nota 42.

40. Puede decirse que la mujer "esgrime " literalmente un argumento que le va a salvar la vida : la espada. La mujer se salva concibiendo un guión teatral y representándolo. En esta singular puesta en escena, la mujer acumula eficazmente las funciones de guionista, directora y actriz. 
Pallium $^{41}$...................................... Mujer : hay dos : la esposa adúltera y la alcahueta. Instrumento del engaño : un paño con tres quemazos ${ }^{42}$. Desenlace : el marido pide perdón a la esposa adúltera.

Elephantinus Mujer: si no es adúltera, se comporta como si lo fuera. Instrumento del engaño : una figura hecha con miga de pan que representa el colmillo de un elefante ${ }^{43}$.

Desenlnce : el marido acepta como verosímil la explicación de la mujer.

Ingenia Mujer : adúltera.

Instrumento del engaño : la astucia de la mujer.

Desenlace : amante burlado.

Tampoco aquí el orden de los cuentos está inmotivado. El último cuento, por ejemplo, es la síntesis de todos los anteriores : de ser objeto de la ejemplificación, el engaño de las mujeres (su capacidad ilimitada para engañar) pasa a convertirse en objeto mismo del discurso, esto es, en tema declarado del cuento. El comportamiento que los otros relatos denunciaban únicamente a través de las acciones de los personajes femeninos, el narrador lo denuncia explícitamente dentro del espacio del propio cuento, poniendo inmediatamente al lector en presencia de un omne que non quería casar fasta que sopiese e aprendiese las maldades de las mugeres e los sus engaños (p. 132). Lo que los otros cuentos ejemplificaban éste, de algún modo, lo desejemplifica poniéndolo al desnudo, de modo que los cinco objetos emblemáticos del engaño -el papagayo, la espada, la perrita, el paño y la figurita de pan- no son sino manifestaciones específicas del «ingenio " de las mujeres, aquí compendiado en lo que podría formularse mediante la ecuación Avis + Gladius + Canicula + Pallium + Elephantinus = Ingenia, cifra a la vez de todas las artes de las mujeres y de todos los relatos anteriores.

En cuanto al primer bloque de cuentos narrados por los privados, observamos que, con excepción de Nomina, de orientación resueltamente misógina, todos los demás se presentan como "variaciones " narrativas sobre el mismo " tema » didáctico : la prudencia. Con el motivo del arrepentimiento como trasfondo, se

41. En este sorprendente exemplum, el castigo llega antes que el adulterio: paradójicamente, la esposa, hasta ahí inocente, deberá consumarlo para demostrar que no lo ha cometido (!).

42. El trozo de tela por quien viene el escándalo es a la vez el objeto que inculpa a la mujer y el objeto que la disculpa. En tres de los seis cuentos en que se disimula el adulterio (Avis, Pallium y Elephantinus), el objeto que incrimina a la mujer es el mismo que, mediante una hábil recontextualización, acaba inocentándola. El discurso plantea así el problema de la interpretación de los indicios y, más allá, el de la lectura y el de la manipulación a través del exemplum. La maestría de las mujeres consiste én invertir la significación de todos estos objetos inventándoles un nuevo contexto que los resemantiza a favor suyo y convirtiendo el indicio que las delata en prueba que las inocenta. Lo que hace la mujer del cuento subvirtiendo la significación de estos indicios es lo mismo que lo que hace la mujer del relato marco y, a nivel más general, que lo que hacen todos los narradores del libro. Todo ejemplo supone una manipulación, aunque sólo sea por la selección -nunca inocente- que efectúa entre todos los representantes metonímicos posibles del concepto, objeto o hecho que se pretende ilustrar. Lo mismo puede afirmarse, en el ámbito general de lo que comúnmente se da en llamar literatura "sapiencial ", de los principios morales argüidos por los personajes contendientes. Como acertadamente apunta Anne-Marie Capdeboscq citando a Julius Evola, las normas morales « son como la balsa que se construye para atravesar un río, pero que se abandona nada más cruzarlo" ( Calila e Dimno ou la morale introuvable", Les langues néo-latines, 295, 1995, p. 159 -la traducción es nuestra-).

43. ¿ Símbolo fálico o simple escarnio del marido cornudo ? Cf. supra nota 42. 
trata de que el rey no actúe sin calibrar antes las consecuencias desastrosas que una condena a muerte pronunciada precipitadamente podría acarrear. Lo que quiere decir que, en todos los cuentos de la serie, aparece siempre un personaje que representa al rey Alcos:

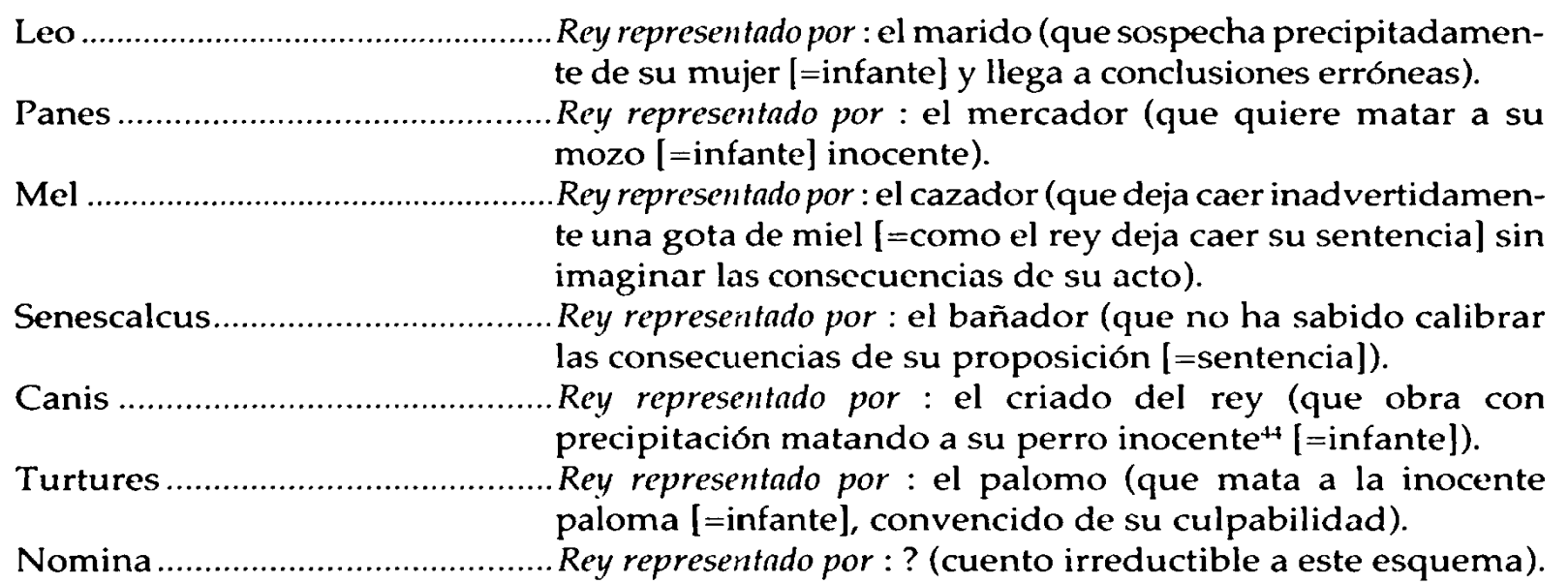

El argumento de Nomina no permite establecer ningún paralelo entre el rey del relato marco y ninguno de los tres personajes que intervienen el cuento, salvo, claro está, que en el antojadizo e irreflexivo comportamiento del marido, que sigue ciegamente los consejos de su esposa pidiendo primero una cosa y luego otra para acabar reclamando lo que pidió la primera vez, se vea una crítica zafada de la veleidad del rey condenando e inocentando alternativamente y no menos irreflexivamente a su hijo, lo que -dicho sea de paso-, aunque discutible (dado que semejante estrategia no redundaría en beneficio de los privados ni del infante), no resulta completamente descabellado si se reconoce la aptitud del discurso ejemplar para desarrollar, por trasposición analógica, deductiva o inferencial, contenidos derivados y para generar lecturas paralelas y, por así llamarlas, subterráneas o incluso subliminales, a veces contradictorias con el objetivo declarado, pero nunca inocentes (ejemplo: Aper, donde el correlato de rey no es otro que un puerco). Y leído así, el cuento resultaría desde luego mucho menos incongruente y gratuito de lo que parece a primera vista... A pesar de lo cual y no obstante la posición que ocupa dentro del libro, no cabe incluir Nomina dentro de la serie. De su indiscutible adscripción al segundo conjunto de narraciones da cuenta la fórmula ritual las maldades de las mugeres non an cabo nin fin que sirve de exordio a éste y a los demás cuentos misóginos del libro. De todo ello se desprende lógicamente que el cuento Nomina ha usurpado el puesto de otro relato, hoy

44. El paralelismo con el infante es tanto más estrecho si se considera la situación de absoluta indefensión en que se encuentra el perro, bañado en sangre, a la llegada de su amo : como al infante, todos los indicios lo acusan y, como él, se encuentra en la imposibilidad de defenderse. Convención del género, la antropomorfosis animal es también, como puede apreciarse aquí, objeto de manipulación: el loro de Azis, el león y el mono de Simia y las palomas de Turtures hablan, pero el desdichado perro de este cuento, antropomorfizado " ma non troppo"-lo suticiente para falagarse l... por lo que avia ficho, pero no lo bastante para poder hablar-, está condenado por el narrador, como el infanté lo está por Cendubete, a guardar silencio. 
perdido o cuando menos por identificar, que presumiblemente ejemplificaba los riesgos de la conducta precipitada y que hacía intervenir entre sus personajes a un alter ego del rey.

\section{Reflexividad de la escritura : algunos efectos espec(tac)ulares}

La estudiada organización textual y la metódica distribución de los cuentos en el libro, son reflejo de un esmerado trabajo de ordenamiento del material narrativo y, de modo concomitante, indicio de un cuestionamiento implícito de la escritura, de sus resortes y sus mecanismos. Presente de un cabo a otro de la obra, esta reflexión metanarrativa se inicia ya en la introducción, en que se urde el hilo que hilvanará los veintitrés exempla del libro. Porque sin conflicto no hay ficción narrativa, la introducción multiplica los obstáculos a que deben enfrentarse los personajes, aboliendo cada vez -para volver a restaurarlo inmediatamente después- el equilibrio a que se había llegado tras la resolución del conflicto anterior. En efecto, como para poner de manifiesto el poder demiúrgico del narrador, los obstáculos se desvanecen a medida que van surgiendo, encadenándose según un esquema recursivo : el rey virtuoso vive rodeado de sus noventa esposas, pero no tiene descendiente ; consigue tener un hijo, pero el infante no tiene disposición natural al estudio ; consigue dar con el maestro ideal para la educación de su hijo, pero la corte de sabios lo desacredita... Cada conflicto, como puede verse, es producto de una privación. Así, vemos aparecer sucesivamente a un rey sin heredero, a un heredero sin sabiduría y a un sabio sin aptitudes pedagógicas ${ }^{45}$, lo que convierte a cada uno de estos personajes -un monarca omnipotente, pero impotente ${ }^{46}$, un príncipe inteligente, pero ignorante ${ }^{47}$ y un filósofo sabio, pero incapaz de transmitir su saber ${ }^{18}$ - en la negación misma de lo que son o de lo que se supone que deben representar ${ }^{49}$, a saber : el linaje (rey estéril), la sabiduría (príncipe analfabeto) y el arte de su transmisión ${ }^{50}$ (sabio incompetente).

Puesto que el conflicto que dará pie a la acción narrativa no guarda aparentemente relación directa con todos estos prolegómenos (el cuento podría haberse iniciado, por ejemplo, con la maquinación de la madrastra y

45. $O$, cuando menos, que ha fracasado ya en el intento de iniciar al infante y de transmitirle la sabiduría.

46. “ E este rey era señor de gran poder $[. .$.$] e [...] avía noventa mugeres. Estando con todas, según era$ ley, non podia aver de ninguna dellas fijo " (p. 65).

47. "E el Infante creçió e fízose grande e fermoso e diole Dios muy buen entendimiento [...] púsolo el Rey aprender que $\mathrm{l}^{\prime}$ mostrasen escrevir, fasta que llegó a hedat de quinzé años, e non aprendié ninguna $\cos a n$ (p. 68).

48. “ ¿ Por qué non le enseñaste tú ninguna cosa en estos años que estuvo contigo... ? ", le recrimina a Cendubete uno de los cuatro sabios (p. 69).

49. Cabe incluir el procedimiento dentro de lo que Bernard Dupriez llama "effacement d'objet "y que podríamos traducir por " evicción de objeto ». En el artículo que le dedica, explica el autor: "Le romantique allemand Ceorges Christophe Lichtenberg semble être l'inventeur de ce procédé, qui consiste à circonscrire l'objet du discours de telle sorte qu'il n'en reste rien. Il passe pour un humoriste avec son "couteau sans lame auquel il manque le manche", mais cela répond en lui à une pensée profonde : "J'étais mort avant de naître" " (Gradus. Le's procédés littérairés, Paris, Union Générale d'Éditions, 1984, p. 171).

50. Recuérdese la primera frase del Calila e Dimna, que centra la actividad del hombre sabio en la búsqueda del saber y en la transmisión de ese saber : “ Los filósofos entendidos de qualquier ley et de 
su intento de seducir al infante sin comprometer ni la lógica interna del relato ni su inteligibilidad), es legítimo preguntarse cuál es la funcionalidad de los episodios preliminares dentro de la economía general del relato. A esta pregunta intenta responder María Jesús Lacarra explicando que « la narración se inicia antes del nacimiento del héroe, lo que nos da ocasión para conocer los problemas planteados por su concepción ${ }^{51}$ " y recordando acto seguido las etapas comunes a la infancia del héroe mítico según las definió Otto Rank: " [El héroe] desciende de pad res de la más alta nobleza; habitualmente es hijo de un rey. Su origen se halla precedido por dificultades, tales como la continencia o la esterilidad prolongadas, o el coito secreto de los padres, a causa de la prohibición externa u otros obstáculos. Durante la preñez, o con anterioridad a la misma, se produce una profecía bajo la forma de un sueño u oráculo contra el nacimiento por lo común poniendo en peligro al padre o a su representante ${ }^{52}$ ". Por nuestra parte, diremos que si la acción arranca en un momento anterior al nacimiento del infante no sólo es para darnos a conocer, como con razón apunta la autora, los problemas planteados por la concepción del héroe, sino también (y sobre todo) para dejar constancia de los problemas planteados por la concepción misma del libro en busca de una estrategia narrativa que posibilite, dando origen al relato marco, el engaste de los diferentes cuentos de la colección. Es cierto que todos estos preparativos permiten insistir en el carácter iniciático del proceso de adquisición del saber e introducir motivos como el horóscopo, la numerología hermética o el rito del paso de la infancia al mundo adulto, pero a lo que asiste realmente el lector a través de la problemática gestación del infante es a la no menos problemática gestación del proyecto narrativo del Sendebar. Lo que ofrece la introducción no es, en última instancia, sino la imagen del propio libro construyéndose a sí mismo, concibiendo un móvil narrativo ${ }^{53}$, confeccionando el mortero por que quedarán solidariamente trabados las veintitrés piezas del ensamblaje narrativo : contando la historia de la gestación, nacimiento e infancia del protagonista, el libro cuenta también la historia de su propio engendramiento.

qualquier lengua siempre punaron et se trabajaron de buscar el saber, et de representar et hordenar la filosofía " (ed. de J. M. Cacho y M. J. Lacarra, Madrid, Castalia, 1993, p. 89). La meta del filósofo no es sólo alcanzar la sabiduria, sino también transmitirla eficazmente o, como dice el texto : "representarla" y "ordenarla "; la motivación pedagógica es indisociable de la estrictamente filosófica: el saber sin la pedagogía no es nada.

51. Cuentística mediezal en España: los orígenes, Universidad de Zaragoza, Departamento de Literatura Española, 1979, p. 121.

52. Op. cit., p. 121-122.

53. Aspecto éste que lo diferencia radicalmente del Calila é Dimma. Constantemente evidenciado e incluso ostentado en este último (en que los cuentos se suceden al ritmo de las preguntas que el rey Diçelem dirige al filósofo Burdubén), el pretexto narrativo, mucho más elaborado, queda parcialmente disimulado en el Sendelar detrás de la trama ficcional que, concebida para servir de engaste diegético a los diferentes exempla reunidos, pretende producir un efecto de verosimilitud narrativa, totalmente inexistente en el Calila $e^{\prime}$ Dimna. La estrategia narrativa que uno exhibe, el otro la oculta haciendo que el relato marco sea el primer exemplum del libro. Siguiendo a Gérard Genette, podria decirse que "función" y " motivación " están en relación de simetría inversa en los dos ejemplarios : "ll y a donc une opposition diamétrale du point de vue de l'économie du récit, entre la fonction diune unité et sa motivation. Si la fonction est (grossierement parlant) ce à quoi elle sert, sa motivation est ce qu'il lui faut pour dissimuler sa fonction. En d'autres termes, la fonction est un profit, la motivation est un coût " (citado por Oswald Ducrot y T\%vetan Todorov, Dictionnaire encyclopédique de's science's du langage', Paris, Éditions du Seuil, 1984, p. 147). 
En efecto, las peripecias de los personajes no se acaban ahí : tras haber retirado primero y devuel to después al rey el poder de engendrar, al hijo la posibilidad de aprender y al sabio la facultad de enseñar, el narrador priva al infante de la palabra : el hijo único del rey Alcos, sobre quien pesa el nefasto vaticinio hecho por los sabios, acaba perdiendo el habla. El infante no escapa, pues, de las predicciones astrales, pero su destino estaba escrito ya, antes de que lo dictaminaran las estrellas, en su propio nombre, convertido en nombre propio : sólo « el que no habla » puede con toda legitimidad aspirar al título de in-fante.

Más allá de la estrategia de legitimación onomástica que representa aquí la pérdida del habla, promoviendo al estatuto de verdadero epónimo lo que no es, en rigor, sino un nombre común, el silencio de siete días impuesto por Cendubete al infante es también una estrategia de legitimación narrativa. Lo que está en juego en la introducción -en la que se erige el andamiaje narrativo que, como todo andamiaje, desaparecerá una vez consolidado el edificio textual ${ }^{54}$ y echada a andar la maquinaria narrativa- es la coartada misma de la escritura : el silencio. $Y$ es este silencio el que, introduciendo la dialéctica palabra / mutismo, dará pie, en primer lugar, al duelo verbal entre madrastra y validos desarrollado a lo largo del libro ; el que engendrará, después, el consiguiente juego de sustituciones, de personajes vicarios y de transposiciones analógicas ; el que avivará, por último, el prurito narrativo del infante cuando, superada la prueba del silencio, empalme uno tras otro cinco cuentos distintos en desagravio de su pasada mudez. La totalidad del Sendebar se construye, así, en torno a un vacío estructurador -el silencio- sin el cual, sencillamente, el libro no existiría : un silencio virtuoso (bona taciturnitas), radicalmente opuesto al silencio culpable (mala taciturnitas, vicio « nefando » al pie de la letra), o incluso un silencio " excelente " si nos remitimos a la tipología del Speculum universale de Raoul Ardent, quien distinguía entre el "silencio malo » del que se calla ocultando lo que sabe, el « silencio benigno » del que se calla porque no tiene nada sensato que decir y el « silencio excelente » de quien, como el infante, se calla esperando el momento oportuno para hablar. Porque de lo que se trata aquí es de neutralizar la palabra culpable de la madrastra, perfecto compendio de los "pecados de la lengua ${ }^{55}$ »-detractio, mendacium, contentio, etc.- a cuyo recuento y tipificación se dedicaron con tan denodado tesón los tratadistas medievales ${ }^{56}$, mediante un silencio productivo, de cuya virtud redentora da sobrada cuenta el feliz desenlace del libro. En este contexto, no puede sorprender el que el primer cuento del infante tenga como motivo central una vasija de leche envenenada (Lac venenatum), siendo la leche, por definición, imagen emblemática de la madre nutricia, una madre incapaz aquí de " secretar » otra cosa que veneno ${ }^{57}$. Y tampoco puede sorprender

54. Debo el símil arquitectónico a Vadine Ly.

55. Carla Casagrande, Silvana Vecchio, Les péchés de la langue, Paris, Cerf, 1991.

56. Entre otros, Albertano de Brescia con su Doctrina loquendi et tacendi (siglo XIII).

57. Narrado en el momento en que los personajes de la ficción principal se plantean, culpándose unos a otros, la cuestión de averiguar quién habría tenido la culpa si el infante hubiera sido ejecutado, el cuento pretende ser una ilustración del debate del relato marco. La conclusión a que llega el infante (Ninguno destos non ovo culpa, mas açertóseles la ora en que arién a morir) resulta mucho menos inocente si, considerando el cuento como un verdadero enigma, se coteja la lista de los personajes en el orden 
el que, prolongando la imagen alimentaria de este cuento, los dos siguientes (Puer IV annorum y Puer $V$ annorum ${ }^{58}$ ) asocien invariablemente el alimento a la sabiduría, como si todo lo que sale por la boca debiera compensarse inmediatamente haciendo entrar alimento por ella o, lo que viene a ser lo mismo, como si la palabra prodigada en forma de consejo sabio fuera producto de la transubstanciación del alimento ingerido : más allá de la paronimia implícita entre saber y sabor, el discurso escenifica a su manera la etimología isidoriana según la cual la boca recibe el nombre de os « porque por ella, como por una puerta (hostium), entra la comida y salen las palabras ${ }^{59}$ ».

Nada impide, pues, ver en la concatenación de estos tres cuentos $-y$ a imagen, entre otros ciclos narrativos, de la serie formada por los tres cuentos del diablo- la materialización de una voluntad ordenadora, singularmente atenta a la cohesión arquitectónica del libro. Habida cuenta de la dimensión metatextual del discurso sendebaresco, nada impide imaginar tampoco que, en un aturdidor juego de engastes auto-recursivos y prefigurando la espectacular mise en abyme del célebre cuento cortazariano ${ }^{60}$, el libro que tiene entre las manos el rey del primer cuento (Leo) y que acabará desbaratando su concupiscente proyecto $^{61}$, sea el mismo espejo de príncipes que tiene entre las manos el propio lector del Sendebar : el que el primer cuento de nuestro libro condene el adulterio poniendo simultáneamente al lector en presencia de un personaje que, a su vez, aparece leyendo el primer capítulo de un libro de leyes e juizios de los reyes en el que, precisamente, se explica cómo debe el adulterio ser defendido, puede ciertamente parecer fortuito, pero la coincidencia es demasiado acuciante como para desechar sin reflexión la posibilidad de que el cuento inaugural ${ }^{62}$ sea escenario de un vertiginoso bucle auto-referencial ${ }^{63}$. Igualmente significativo a

en que son incriminados en la ficción principal (1. Cendubete, 2. el rey, 3. la madrastra, 4. el propio infante) y en la ficción subordinada (1. el huésped, 2. el milano, 3. la serpiente, 4. la moza). Efectivamente, la madrastra ocupa en la primera exactamente la misma posición que la serpiente en la segunda (del mismo modo que se hace corresponder a Cendubete con el huésped, al rey con el milano y al infante con la moza), lo que autoriza a decir que las palabras son a la madrastra lo que el veneno es a la serpiente. Parcialmente anunciada ya en Canis (« vino a él [el niño] una culcbra muy grande, $e$ quísolo matar por el olor de la leche de la madre ", p. 115), la asociación aquí soterrada aparece claramente desarrollada en la Scala çeli de Diego Cañizares : "Entonçes ella quiso asir dél, y el Infante comenzó a huir por la cámara, y la Emperatrix entonçes, como madrastra y así como sirpiente, començó de infundir y derramar su peçoña... "(ed. de Ángel González Palencia, p. 72-73).

58. "Yo te daré consejo a esta cueita que as, si me dieres un dinero con que conpre dátiles" (p. 146).

59. Etimologías, XI, 1, 49.

60. Nos referimos, claro está, a Continuidad de los parques.

61. Función que en el cuento Puer IV annorum desempeñará el niño sabio, imagen antropomórfica del libro del cuento Leo.

62. Más sorprendente aún si cabe es la progresiva derivación anagramática que conduce sucesivamente del título del cuento (LEO) al nombre que designa su referente (REY), pasando por un significante intermedio (LEY) en que convergen tanto el sustantivo derivado de legem (« ley-1") como el imperativo del verbo leer ( ley-2») : E quando torno, diol' un libro de su marido en que avía leyes y juizios de los reyes, de cómmo escarmentavan a las mugeres que fazían adulterio. E dixo : -Señor, ley por ese libro fasta que me afeinte " (p. 79). La cadena semiótica leo $\rightarrow>l e y-1 \rightarrow>l e y-2 \rightarrow>$ rey, convierte a) significante leo en una verdadera fórmula generativa, en la que tal vez no esté completamente excluido leer, precisamente, la primera persona del verbo leer.

63. En el sentido plenamente informático del término (cf. Douglas Hofstadter, " Temas metamágicos ", Investigación y ciencia, núm. 54, mayo de 1981, p. 102-106 y, en colaboración con Daniel Dennett, Vues de l'esprit, Paris, Inter-Éditions, 1987). 
este respecto es que el motivo del libro no vuelva a aparecer hasta el último relato del último valido -esta vez en forma de libro sobre las artes de las mujeres-, delimitando así el espacio reservado al debate entre la acusación y la defensa y cerrando el proceso jurídico del careo de los testigos. A la vista de todo lo cual no parece infundado afirmar que el principio que, a nivel macroestructural, define la organización general del libro sigue operando también dentro de cada grupo de cuentos, estableciendo conexiones entre ellos y definiendo series más o menos homogéneas y ordenadas : así, por ejemplo, si Leo nos presenta a un personaje inocente que parece culpable, Avis, el cuento siguiente, nos presenta inversamente a un personaje culpable que consigue pasar por inocente; del mismo modo, el cuento Panes, que reproduce mediante el binomio mercador / mozo la relación padre / hijo del cuento anterior, se corresponde con Lavator, que invierte esta relación haciendo que el personaje que cae en desgracia por querer salvar a su hijo en éste caiga en desgracia por querer condenarlo en aquél ; y si, unidos por el personaje del diablo, Striges, Nomina y Fontes pueden considerarse como un subconjunto coherente dentro del libro, lo mismo puede decirse de Canicula, Aper, Canis y Simia por presentar en perfecta y simétrica alternancia los personajes perro / simio / perro / simio.

\section{Otros indicios formales.}

Las conexiones horizontales que, como se ha visto, se establecen entre los diferentes exempla del libro evidencian que, pese a la relativa autonomía de que gozan, los cuentos no se suceden -al menos, no siempre- arbitrariamente sino que, respondiéndose unos a otros, se ordenan o pueden ordenarse formando series como la que forman, según nos hemos propuesto demostrar, los cuentos Striges, Fontes y Nomina. Volviendo ahora a este último exemplum y a la posición que, a nuestro juicio erróneamente, le ha sido adjudicada dentro del libro, quedan por señalar dos hechos de orden estrictamente textual que avalan la hipótesis defendida más arriba. El primero, que confirma que el cuento ha sido desenclavado de su posición original, está relacionado con el marco narrativo dialogado con que da comienzo el primer relato de cada uno de los siete privados. Como es sabido, la primera intervención de cada abogado defensor se organiza con arreglo al mismo esquema, según un juego de réplicas y contra-réplicas fuertemente codificado : tras el anuncio del caso que, destinado a estimular la curiosidad el rey -y a través de éste, la del propio lector-, será ejemplificado por el privado, el rey introduce la fórmula demarcativa ¿ Cómmo fue eso ? que, materializando dentro del propio texto la frontera entre relato marco y relato enmarcado, dará pie al exemplum propiamente dicho. Este sistema de indicadores textuales y de balizas internas, que contribuye eficazmente a reforzar lo que, a propósito del Arte de la novela, Milan Kundera llama «claridad arquitectónica» de la obra, lo encontramos fielmente reproducido en el cuento Nomina, como lógicamente corresponde a su estatuto de relato inaugural (primer cuento de la serie de dos que está a cargo de cada uno de los siete privados) : 
Por ende te dó por consejo sinon que non mates tu fijo, que las maldades de las mugeres non an cabo nin fin; e desto darte é un enxemplo. E dixo el Rey: - ¿Cómmo fue eso? (p. 130)

Pero, a diferencia de lo que ocurre en los relatos anteriores, el mini-diálogo entre privado y rey se encuentra anormalmente desplazado al final del cuento cerrando, en lugar de abrirla, la narración del valido ${ }^{64}$. El segundo indicio formal confirma la adscripción del cuento a la segunda serie de relatos de la defensa. El cotejo de la primera frase del primer cuento de cada privado demuestra inequívocamente que el orden de los cuentos ha sido trastocado. La presentación de cada privado -arrodillándose ritualmente ante el rey-se hace según una fórmula introductoria igualmente ritualizada y codificada, que incluye invariablemente la indicación del narrador que interviene : 1. «Este privado primero fuese para el Rey e fincó los inojos ante él, e dixo " (Leo), 2. «E vino el segundo privado e fincó los inojos ante el Rey e dixo »(Panes), 3. «E vino el terçero privado ante el Rey e fincó los inojos ant'él e dixo » (Mel), 4. «E vino el quarto privado, e entró al Rey e fincó los inojos, e dixo» (Senescalcus), 5. «E vino el quinto privado ante el Rey e dixo» (Canis), 6. «E vino el seseno privado, e fincó los inojos ante el Rey, e dixo » (Turtures). Frente a esto, el cuento Nomina empieza como lo hacen todos los cuentos misóginos de la segunda serie, esto es, sin indicación expresa del narrador : «E señor, oi dezir que era un omne que nunca se partía de una diableza...». Habida cuenta de la rígida y calculada estructura general del Sendebar resulta difícil no ver en este desajuste un nuevo indicio del trastrueque que ha sufrido el orden original del libro.

Teniendo en cuenta, en primer lugar, los indicios formales que denuncian materialmente el desplazamiento de que ha sido objeto el cuento, en segundo lugar, su clara pertenencia al ciclo misógino de la defensa y, en tercer lugar, la presencia entre sus personajes de la « diableza », puede asentarse con un grado no desdeñable de probabilidad la hipótesis de que : 1) Nomina ha usurpado indebidamente la decimoséptima posición del libro, 2) el exemplum que falta no es el segundo cuento del tercer valido, sino el primer cuento del último privado, 3) Nomina ocupa la posición del cuento que se ha dado por desaparecido y, comprendido entre Striges y Fontes, forma con ellos una especie de tríptico organizado en torno a la figura del diablo :

\begin{tabular}{|c|c|c|c|c|c|}
\hline NÚM & TÍTULO & NARRADOR & DÍA & CONTENIDO & INCIPIT \\
\hline 1 & Leo & Privado 1 & 1 & Defensa & Este privado primero fuese para el Rey... \\
\hline 2 & Avis & Privado 1 & 1 & Misógino & Señor, oí dezir que un omne que era çeloso... \\
\hline 3 & Lavator & Mujer & 2 & Acusación & \\
\hline 4 & Panes & Privado 2 & 2 & Defensa & E vino el segundo privado e fincó los inojos... \\
\hline 5 & Gladius & Privado 2 & 2 & Misógino & Señor, fiziéronme entender de los engaños... \\
\hline 6 & Striges & Mujer & 3 & Acusación & (DIABLA) \\
\hline
\end{tabular}

64. Si consideramos, como hace M.J. Lacarra, que es éste el incipit del cuento siguiente, Ingenia sería el único cuento misógino del libro provisto de marco dialogado introductor. En cualquier caso, no dejaría de haber aquí una anomalía en clara ruptura la regularidad establecida por los relatos anteriores. 


\begin{tabular}{|c|c|c|c|c|c|}
\hline NÚM & TÍTUlo & NARRADOR & DÍA & CONTENIDO & INCIPIT \\
\hline 7 & Mel & Privado 3 & 3 & Defensa & E vino el terçero privado ante el Rey... \\
\hline$\left(^{*}\right)$ & ? & ${ }^{\star}$ Privado 3 & *3 & ${ }^{*}$ Misógino & \\
\hline 8 & Fontes & Mujer & 4 & Acusación & (DIABLO) \\
\hline 9 & Senescalcus & Privado 4 & 4 & Defensa & E vino el quarto privado, e entró al Rey... \\
\hline 10 & Canicula & Privado 4 & 4 & Misógino & Señor, oí dezir que un omne a su muger... \\
\hline 11 & Aper & Mujer & 5 & Acusación & \\
\hline 12 & Canis & Privado 5 & 5 & Defensa & E vino el quinto privado ante el Rey e dixo... \\
\hline 13 & Pallium & Privado 5 & 5 & Misógino & Señor, oí dezir que avía un omne que... \\
\hline 14 & Simia & Mujer & 6 & Acusación & \\
\hline 15 & Turtures & Privado 6 & 6 & Defensa & E vino el seseno privado, e fincó los inojos... \\
\hline 16 & Elephantinus & Privado 6 & 6 & Misógino & Señor, oí dezir un enxemplo de un omne... \\
\hline$\ldots$ & {$[\ldots]$} & Mujer (prot.) & 7 & Suicidio & \\
\hline 17 & Nomina & Privado 7 & 7 & Misógino & E señor, oí dezir que... \\
\hline 18 & Ingenia & Privado 7 & 7 & Misógino & E Señor, dixéronme que un omne que... \\
\hline
\end{tabular}

El substrato marcadamente erótico que une los tres cuentos invita, por otra parte, a considerar al diablo transexual del cuento octavo como un personaje tránsfuga que transita libremente de un cuento a otro ${ }^{65}$ encarnándose respectivamente, como si de avatares sucesivos del mismo monstruo se tratara, en niña (Striges), en diablesa (Nomina) y en diablo bisexual (Fontes). Así por ejemplo, el cuento analizado en la primera parte de nuestro estudio pone de manifiesto el dimorfismo sexual del diablo, monstruo polimorfo que, capaz de asumir indistintamente durante el coito el papel de hembra y el de hombre, encarna el fantasma de la unidad sexual. Si, en el estado en que el cuento ha llegado hasta nosotros, nada permite asentar ni descartar la posibilidad de que el diablo haya podido tener trato sexual con el infante, su figura no deja de estar vinculada a la tentación carnal, como así demuestra el que reaparezca más adelante en lugar de muger preñada. De hecho, si en el cuento 8 el diablo se apiada del infante, no ocurre lo mismo en el cuento 6, donde la niña-diabla, asociada desde el título a la striga, esto es, a la bruja, remite directamente a un referente cultural perfectamente definido : « la striga -apunta Claude Lecouteux - reviste un carácter maléfico, es una fornicadora y una especie de antropófaga que se entrega de noche a abominables festines con sus congéneres $^{66} \gg$. Efectivamente, la asimilación de la bruja a la prostituta está atestiguada ya desde el siglo VI en la Ley sálica, donde los términos strigae y fornicariae aparecen como sinónimos intercambiables, y un siglo más tarde en el Edictum Rothari, donde puede leerse : si quis puellam aut mulierem liberam, qui in alterius mundium est, fornecarium aut strigam clamaverit ${ }^{67}$. Es cierto sin embargo que, del diálogo entre la diabla y sus « parientes » interceptado por el infante escondido, el narrador sólo reproduce la frase : vete adelante con él a otro casar fasta que te alcançemos (p. 97). Pero allí donde la versión hispánica apenas si da cuenta del conciliábulo, el Mischlé Sendebar, dejando bastante más claras las intenciones de la congregación de diablas, desarrolla :

65. En su estudio sobre los " hombres-relato", Tzvetan Todorov nos habla de otro tipo de tránsito de personajes, vertical éste, entre la ficción engastada y la ficción principal ("Les hommes-récits : les Mille et une nuits ", Poétique de la prose, Paris, Seuil, 1978, p. 33-46). Frente a este modelo, el Sendebar representaría una transitividad de tipo horizontal.

66. Au-delà du merveilleux. Des croyances au Moyen Âge, Paris, Presses Universitaires de ParisSorbonne, 1995, p. 75 (la traducción es nuestra).

67. Claude Lecouteux, ibidem, p. 73. 
- He aquí que os he traído un príncipe. Lo que deseéis hacer con él, hacedlo.

- Condúcelo a tal lugar. Allí haremos nuestro gusto y nos divertiremos con él, contestaron ellas ${ }^{\text {ss. }}$.

Al mismo arquetipo castrador de la mujer lujuriosa, culpable de su exacerbado apetito sexual, responde el cuento Nomina : doblemente burlado por la « diablesa » y por su esposa, el protagonista, que formula aquí el deseo de tener muchas mujeres (pero que quando se vido cargado d'ellas, dixo a su muger : - ¡ Confóndate Dios que esto por el tu consejo se fizo !), reclama en las Mil y una noches " un miembro mayor " (tan grande " como una calabaza, hasta el extremo de que no podía levantarse $\left.{ }^{69} »\right)$ y pide en el Mischlé Sendebar que se le «llene todo el cuerpo de penes ${ }^{70}$ " (lo que, una vez emitido el deseo de perderlos, hará temporalmente de él un verdadero eunuco). Asociado a la triple imagen femenina de la meretriz, de la bruja y de la diabla, el monstruo, proyección fantasmática de una sexualidad profundamente culpable, ejerce todo su poder de fascinación en tanto que arquetipo simbólico en que cohabitan placer y muerte. Lo que se diaboliza en estos tres cuentos y -más allá de lo que ocurre en lo que hemos llamado aquí el « tríptico del diablo »en el conjunto de la colección es la imagen, eminentemente culpabilizadora, de la mujer dotada de una sexualidad desbordante a la que el hombre es sencillamente incapaz de saciar : traducción mítica del pecado original, el acto concupiscente e incestuoso de la madrastra es, no hay que olvidarlo, el desencadenante de toda la acción narrativa ${ }^{71}$. Y no importa si es un personaje femenino el que, haciendo a la vez de diablo y de abogado del diablo, contribuye con sus propios relatos a estigmatizar la imagen de la mujer: la voz que se expresa a través de la narradora y la fobia atávica que por su boca se exorciza responden indefectiblemente al modelo masculino impuesto por el artífice y conceptor del libro. «Parece ser que cada sexo puede ver en el sexo opuesto un monstruo o, cuando menos, un objeto de temor-subraya Claude Kappler-. Pero en las sociedades en que es el hombre quien expresa sus pensamientos, quien escribe, quien actúa... este temor tiende a manifestarse bajo una sola vertiente ${ }^{72} \gg$. Y es esta vertiente única la que, mediante un simulacro de pleito, insidiosamente trucado desde la primera línea y preprogramado en su totalidad a partir de la sentencia final ( $E$ el Rey mandóla quemar en una caldera en seco), se ofrece, omnimodamente ejemplificada, al lector del Sendebar.

68. P. 65.

69. Noche 596, p. 343.

70. P. 86.

71. En su tesis doctoral Variantes occidentales castellanas del "Sendebar": ciclo de "Los siete sabios de Roma ", Madrid, Editorial de la Universidad Complutense, 1990, p. 316-346, Ventura de la Torre rastrea el "mitologema" de la falsa acusación de delito sexual (lo que el autor llama " tema nuclear de inserción discursiva ") en el mundo clásico, en los relatos indios y del extremo oriente, en Egipto y Mesopotamia, en la tradición biblica (relato de José y la mujer de Putifar) y en la cultura árabe y europea.

72. Monstres, démons et merveilles à la fin du Moyen Âge, Paris, Payot, 1980, p. 265 (la traducción es nuestra). 